\title{
EDUCATIONAL MANAGEMENT STRATEGIES IN OPHTHALMOLOGY SPECIALTY PROGRAMS
}

\author{
Valdez-García $\mathrm{JE}^{1 *}$, Lopez $\mathrm{M}^{1,2}$ and Olivares-Olivares $\mathrm{SL}^{1}$ \\ ${ }^{1}$ Tecnologico de Monterrey, Escuela de Medicina y Ciencias de la Salud, Mexico \\ ${ }^{2}$ Writing Lab, Institute for the Future of Education, Tecnologico de Monterrey, \\ Monterrey, Mexico
}

\begin{abstract}
Medical specialty programs are aimed to train doctors in a specialization closely intertwined with a professional context. Progressively physicians experience more complexity and responsibility under the supervision of tutors and institutions approved for such purposes. For this program to be feasible to implement, institutions rely on their educational management strategies to plan, organize, lead, and control their process. This study aimed to assess these educational management strategies in specialty programs. The approach in this study was quantitative, with a descriptive and cross-sectional design. The sampling strategy was a convenience sample that consisted of the assessment of 22 programs of Ophthalmology. The assessment used an instrument of 13 items with a Likert scale of 5 levels ranging from 1, which stands for strongly disagree, to 5 , which represents strongly agree. Results show a mean of 3.7 on the total scale, with a standard deviation of 1.4. The educational management strategy with the most favorable response was planning $($ mean $=3.9)$, and the least favorable response was found in leadership $($ mean $=3.5)$. These results indicate that educational institutions in health and medicine, particularly in Ophthalmology programs, have neglected to develop some management strategies, which must need to develop systematically. The universities must consider the establishment and adherence to good practices and policies, as these are part of establishing a quality educational program. A systematic analysis is needed to document and reflect the development, management, and institutional assessment of these strategies.
\end{abstract}

Keywords: educational innovation, higher education, medical education, educational management, ophthalmology

\section{Introduction}

The tremendous economic, political, and cultural changes in society have proposed new challenges for educational institutions, which require more significant participation in institutional processes to guarantee the quality of educational programs (Alvarez, Puentes, Guzmán \& Vidal, 2009). The administration or management of educational programs applies universal concepts of the administration theories for the operation, and definition of principles and purposes of the institution, teaching, and didactic resources, pedagogical strategy, regulations to follow, and an integrated business system (Flores, Sánchez, Coronado \& Amador, 2001). Whether an educational institution is located in the sandy beaches in Mexico, the green valleys of Ireland or a one-teacher school in Northern Alberta, the educational planning task is identical: to mobilize resources that are available to achieve the agreed objectives (Douse \& Uys, 2018).

Particularly in health education centers, it is a challenge to align the institution's needs as an educational project and the particular needs on honoring the responsibilities to the communities 
health. The educational plans must be focused on integrating innovation to solve the educational needs and to observe the social responsibility to their communities they serve (Olivares, Garza \& Valdez, 2016). In the postgraduate level of studies, also known as medical specialty programs, the aim is to train doctors in a clinical specialization; therefore, the programs are closely intertwined with the culture of their professional context (Lopez, Olivares \& Heredia, 2020). Progressively physicians experience more complexity and responsibility under the supervision of tutors and institutions approved for such purposes. For these programs to be feasible to implement, institutions rely on their educational management strategies to plan, organize, lead, and control their process (Olivares, Garza, Lopez \& Suárez, 2016). The research objective was to assess these educational management strategies in Ophthalmology specialty programs, to understand the organizational management strategies in graduate programs, particularly in medical specialty programs in Ophthalmology where the authors participate as administrators and faculty members.

\section{Educational management}

Management focuses on regulating the entire organization's efforts to achieve objectives by defining a plan, strategies for management, action to meet that vision, and tools to make measurement focused on continuous improvement (Havinal, 2009). Diverse functions can be described in the context of an organization's administration, which are oriented to the integral administration. Some authors describe the subject of organizational management based on the administrative functions that are carried out. Knowledge of the elements and principles of management grants to the administrator the power to organize any operation.

Educational management is a central concept to truly understand an organization, as it carries the responsibility for the proper functioning of a system (Connolly, James \& Fertig, 2017). A few other names that have been used to describe it are educational leadership or educational administration (Adams, Kutty \& Zabidi, 2017). Some of the principles that fuel its structuring are division of labor, authority, discipline, scalable chain of command, equity, subordination of individual interests to collective interests, initiative and spirit of cooperation, principles that support the planning and development of the organizational structures today (Naidu, 1996). Other authors have focused on the division of labor and coordination as fundamental to rational economics, efficiency, and management productivity. These refer to the concept of departmentalization in four criteria: purpose, processes that comprise it, people or public they serve, and the place where the work takes place (Rabin, Humes \& Morgan, 1984). The administrators employ the ability to exercise the cuts that must be observed between the authorities to govern the action. If no order is followed, the design becomes inefficient and presents waste (Naidu, 1996).

These different functions must be part of educational institutions' administration dedicated to the training of medical specialty programs, which are: planning, organization, leadership, and control.

\section{Planning}

Planning is crucial within an organization since it determines where it wants to go, organizing the fundamental purposes to achieve its objectives (Lederer \& Mendelow, 1987). To do this, the different actors in charge of planning must consider factors such as the organization's mission and purpose, the environment, resources, and values, all of which form a frame of reference for decision-making 
processes (Burrow \& Kleindl, 2013). An essential point about planning is that it helps to think beyond daily activities, guides preparedness for challenges, and plans for the future.

According to Burrow and Kleindl (2013), there are different planning types: strategic, tactical, and contingency. Strategic planning is defined as long-term planning that focuses on the entire organization and is located at the highest levels were managed by executive directors, presidents, and leaders of the organization. Strategies must be consistent with the purpose and mission of the organization. Tactical planning is characterized as a short-term planning. This type of planning is more focused on current operations, and as such, those in charge of them are lower-ranking personnel since they are designed from one week to another or from one month to another.

For Havinal (2009), planning involves defining what should be done, how to take action, and when. In the context of the operation of a medical specialty program, there must be the definition of objectives for the short term and a committee in charge of ensuring compliance with that plan. Likewise, there must be mechanisms so that strategic planning includes managing resources and verifying impact and said resources' tactics.

\section{Organization}

Organization refers to the implementation of instruments to depict order (Reyes, 2007). This necessarily implies the conjunction of three elements: a) the definition of specific functions, b) the orientation of the various functions towards a single purpose, and c) the coordination of the different parts or units with each other. Starting in the eighties, new organizational models appeared (Rivas, 2002). For example, Mintzberg's organic model considers two administrative operations models: the professional bureaucracy and the adhocracy (Lamond, 2003). The first is that the organization's essential part is usually in the functional group. Its basic premise lies in the standardization of skills. Its contingent factors can be described as complex, with stable and unregulated environments, in which an unsophisticated and adaptable technical system is evident. Therefore, the support departments, such as cafeteria, library, support services, and scholarship department, are usually large since support is a fundamental part of its structure.

In adhocracy, the basic coordination mechanisms are based on their adjustments. Unlike other structures, the organization's essential part lies in both the operational and administrative teams. This model is usually characterized by containing organized structures with important coordination mechanisms. The experts are the ones who hold power since they are usually professionals whose skills are scarce in the market since they require a great deal of education and training.

Authors such as Havinal (2009) define this task as the habit of distributing or balancing work according to employees and work groups' profiles, delegating functions and objectives according to their functions and operation possibilities. In the context of medical specialty programs, the medical unit that receives residents must have a solid administrative body that guarantees the smooth operation of the program, that is, a solid structure of the bureaucratic model that offers flexible and efficient solutions typical of the adhocratic model. Programs must have financial support through sponsorships for tuition and various residents' living expenses for this operation. Within the university, budgetary funds must be administered to develop the program's academic activities (Estrada, 2014). 


\section{Leadership}

The concept of leadership has evolved as much as human development changes (Gómez-Rada, 2002). Currently, leadership is characterized by key figures who implement teamwork principles and the incorporation of technology that allow them to efficiently analyze and synthesize the information they are receiving for decision-making. On the other hand, they must understand that their administration has to do with people, not with indicators or projects, these leaders must be able to motivate their team, so they depend on listening to discover what people need or want.

Havinal (2009) attributes this role to the leader and his ability to show through communication, influence, and motivation skills. The new leadership perspectives developed by Bass (1990) focus on transactional and transformational leadership. The transactional approach refers to the daily operation in a medical specialties program; it describes that the director of the program has adequate time to manage the program. In the transformational, the focus is beyond; it focuses on team building and collaboration between different levels of an organization and other organizations to achieve change. This second approach describes the generation of agreements between the hospital and the medical units and the receiving medical units of the residents. As well as the constant renewal of these agreements.

\section{Control}

This administrative function culminates the previous functions, since once the objectives of the organization have been defined and implemented, individual verification is required on whether progress is met. Havinal (2009) defines that control has three elements: establishing standards, measuring current performance, and taking corrective actions when they are not fulfilled.

In medical specialty programs, it would be for the program to have a committee to ensure its proper development. Also, residents receiving academic credits must have accreditations from a local, national or international body that legitimizes their operation. On the other hand, the university must demonstrate, through an evaluation, the institutional commitment to the program (Estrada, 2014).

\section{Methods}

This study's approach is quantitative, descriptive, and cross-sectional (Hernández, Fernández \& Baptista, 2006). It is considered quantitative due to its positivist vision of the world, where stable social facts can be measured through variables (McMillan \& Schumacher, 2006). According to the same authors, it is identified as descriptive because it evaluates the nature of the existing conditions, limiting itself to the characterization of something as it is. Finally, it is cross-sectional as it represents a glance of a specific moment in this study population.

The present study was focused on the self-evaluation of 22 medical specialty programs in Ophthalmology through a survey of 22 participants in leadership positions (directors, deputy directors, and coordinators of residency programs). The study used a convenience sampling strategy (Gordillo, Medina \& Pierdant, 2012) during the Workshop for Directors and Teachers of Residency Programs organized by the Mexican Society of Ophthalmology and the International Council of Ophthalmology in Mexico city. 
The 13-item instrument is derived from the model defined by Estrada (2014) and evaluates each criterion using a 5-level Likert scale that ranges from 1 totally disagree to 5 totally agree. The items are presented in Table 1, classified according to the function they represent. This study's analysis considers descriptive statistics to evaluate the trends in the different items and factors that make up the proposed theoretical model. The standard deviation and the $95 \%$ confidence interval by factor were also calculated.

This research considered the methodological recommendations for information treatment defined by Gordillo, Medina, and Pierdant (2012). The participants who answered the survey were informed about its purpose for educational research purposes and freely collaborated in this study.

\section{Results}

The instrument's general results indicate a mean of 3.7 and a standard deviation of 1.4. When analyzing the results by item, the highest was 1)The program has a formal document that outlines the program's general objectives, with a mean of 5. The lowest item was 10)The agreements are frequently renewed with a mean of 3.0. These results are presented in Table 1.

Table 1: Descriptive statistic by item

\begin{tabular}{|c|c|c|c|}
\hline Dimension & Item & Mean & $\begin{array}{l}\text { Standard } \\
\text { deviation }\end{array}$ \\
\hline \multirow[t]{3}{*}{ Planning } & $\begin{array}{l}\text { 1) The program has a formal document that outlines the general } \\
\text { objectives of the program. }\end{array}$ & 5.0 & 0 \\
\hline & 2) The Program committee meets the objectives that were set. & 4.2 & 0.5 \\
\hline & $\begin{array}{l}\text { 3) The resources used in the program's management and that have } \\
\text { contributed to achieving the desired results were proportional to the } \\
\text { resources planned. }\end{array}$ & 2.7 & 1.1 \\
\hline \multirow[t]{3}{*}{ Organization } & $\begin{array}{l}\text { 4) The hospital's medical unit that receives the residents provides } \\
\text { administrative support for the educational program's correct } \\
\text { operation. }\end{array}$ & 4.6 & 0.8 \\
\hline & $\begin{array}{l}\text { 5) The program is sponsored, in terms of tuition and living expenses } \\
\text { of residents, by the medical unit that received the participants. }\end{array}$ & 3.6 & 1.3 \\
\hline & $\begin{array}{l}\text { 6) There is an adequate budget for the university to develop the } \\
\text { program's activities. }\end{array}$ & 3.0 & 1.1 \\
\hline \multirow[t]{4}{*}{ Leadership } & $\begin{array}{l}\text { 7) The director of the medical specialty program has enough time to } \\
\text { manage the program properly. }\end{array}$ & 3.1 & 2.0 \\
\hline & $\begin{array}{l}\text { 8) The program manages agreements with the hospital in which the } \\
\text { medical unit that receives the residents of the program is located to } \\
\text { establish the parties' obligations. }\end{array}$ & 4.1 & 1.6 \\
\hline & $\begin{array}{l}\text { 9) The program has agreements with the medical units receiving } \\
\text { residents. }\end{array}$ & 3.8 & 1.7 \\
\hline & 10) The agreements are frequently renewed. & 3.0 & 2.0 \\
\hline \multirow[t]{3}{*}{ Control } & $\begin{array}{l}\text { 11) The program has a committee that ensures its proper } \\
\text { development. }\end{array}$ & 4.4 & 1.4 \\
\hline & $\begin{array}{l}\text { 12) The medical unit receiving residents is accredited in the } \\
\text { program's specialty before a local, national or international body. }\end{array}$ & 3 & 0.9 \\
\hline & $\begin{array}{l}\text { 13) The institutional commitment by the university regarding the } \\
\text { program is evaluated. }\end{array}$ & 3.8 & 0.6 \\
\hline
\end{tabular}


When analyzing the dimension of organizational management, planning presents the highest mean with 3.9. Simultaneously, the lowest mean dimension was leadership, with a mean of 3.5. These results are integrated into table 2 .

Table 2: Results by educational management dimensions

\begin{tabular}{lll}
\hline & Mean & Standard deviation \\
\hline Planning & 3.9 & 1.18 \\
\hline Organization & 3.7 & 1.29 \\
\hline Leadership & 3.5 & 1.79 \\
\hline Control & 3.7 & 1.16 \\
\hline
\end{tabular}

To assess the instrument's reliability, a Cronbach's alpha was calculated, which resulted in a 0.44 value. Several authors catalog this result as unacceptable to describe an instrument's quality (Vogt, 2007). However, it is important to note that this was the first implementation with a small sample size. The high variability seen in the responses of participants might have led to this value.

\section{Discussion}

Planning proved to be one of the highest categories; however, the vision identified in the organizations is decisive planning of contingencies that something unexpected happens or when something needs to change, it needs an effective manager to solve things. The reflection is that schools should plan preventively and describe contingency plans are beneficial to find alternatives. However, as new technologies are being developed, institutions can rely, as Douse and Uys (2018) envisioned, on planning founded upon digitalization for the Digital Age. Rather than focusing on the best investment to put the resources on, educational planning needs to identify desired outcomes and consequences. Technology can contribute to monitoring besides the distance and become a factor that provides a competitive advantage for the institution (Lopez, Hernandez, Mejía \& Cerano, 2019).

Another category with the highest score was organization, with the items on administrative support for the program's operation and support for the resident's living expenses being the most favored. In Mexico, this is achieved through a link with the Ministry of Health; however, institutional support is also required to maintain and grow the programs. These include, for example, the purchase of furniture for resting areas, as well as equipment for hospital areas. The results are consistent with previous studies carried out. In similar medical organizations, Olivares, Garza, and Valdez (2016) categorized 112 schools according to 5 incremental quality levels: Startup, Development, Standardization, Innovation, and Sustainability, and found that more than 50\% of medical schools have not reached the highest levels. This indicates that health training institutions comply with the declaration of their operation and have defined mechanisms for the programs' operation. However, schools must still implement the vision towards strategic planning and measurement of the achievement of objectives that demonstrates excellence in their operation.

Medical specialty programs must develop the structure that allows decision-making processes. Information flows flexibly and informally. This exercise's fundamental purpose is the constant and systematic promotion of innovation to solve current and future needs. 
The self-evaluation carried out in this research has some limitations, such as the fact that it was an exploratory study with a small sample of programs; however, the effort is worthwhile and can be transferred to other residency programs. Furthermore, this depends on the honesty of the program directors to answer the different items with certainty. Further research could incorporate the evaluation of a panel of experts who could verify in person the institution's operation in different locations. By integrating peers in the assessments, the national operation of the specialty programs could be homologated. In this sense, at least a minimum level of quality between programs could be guaranteed, but more importantly, the programs and directors could share good practices and gather as a group to find solutions to the problems they share. By doing so, programs would see themselves as collaborators rather than competitors. This model must be further proved in different specialty programs to validate the model and integrate the particularities of other programs with more participation with the community or surgical involvement; others also vary in length of years and participants' size. These elements might impact the management practices and budget that the programs administer; therefore, these insights can complement the proposed model.

\section{Conclusion}

The quality management models and systems used in the residency programs contemplate general standards that describe the operation's minimum required. That is why incorporating models oriented towards excellence that trigger cycles of deep reflection on good practices for the training of the new generation of health professionals should be started. As organizations move to visions focused on sustainability, it will be possible to have a genuinely competitive offer indeed.

This study had several limitations as it was conducted in a single postgraduate study program in a single country. The next step for this project would be to integrate more programs within the same context to increase the sampling size. By doing so, a broader picture of the Mexican context could be obtained. Further implementations need to assess its applicability in Ophthalmology programs in different regions to validate the model. Other medical specialty programs could learn of this experience and translate the items to their context; for example, a family medicine program must incorporate the opportunities to interact with the community, and surgical programs could incorporate the specification of the protected time that students must attend to simulated clinical sessions where they can work on the manual techniques and knots procedures. Suggestions for other research groups that want to pursue the topic would be integrating a mixed-methods approach to have a more comprehensive vision of what is happening on the programs. A quantitative study allowed us to have an overall impression to incorporate training programs for leaders to work on their planning and leadership practices; however, to truly construct policies and strategies focused on the programs' strengths and needs, a more profound view is needed.

\section{References}

Adams, D., Kutty, G. R., \& Zabidi, Z. (2017). Educational leadership for the $21^{\text {st }}$ century. International Online Journal of educational leadership, 1(1), 1-4.

Álvarez, G., Puentes, A.V., Guzmán, W., \& Vidal, J.M. (2009). Gestión, un aporte para el mejoramiento de las instituciones educativas. Entornos, 22(1),35-52.

Bass, B.M. (1990). From Transactional to Transformational Leadership: Learning to Share the Vision. Organizational Dynamics,18(4),19-31. 
Burrow, J.L., \& Kleindl, B. (2013). Business Management. Ohio: South-Western Pub.

Connolly, M., James, C., \& Fertig, M. (2019). The difference between educational management and educational leadership and the importance of educational responsibility. Educational Management Administration \& Leadership, 47(4), 504-519.

Douse, M., Uys, P. (2018). Educational Planning in the Age of Digitisation. Educational Planning, 25(2), 7-23.

Estrada, S. (2014). Diseño de modelo de calidad para la evaluación y seguimiento de los programas de especialidades médicas (Unpublished master's thesis). Tecnológico de Monterrey, Monterrey, México.

Flores, R., Sánchez, A., Coronado, M., \& Amador, J.C. (2001). La formación médica en México y los procesos en búsqueda de garantizar la calidad de los egresados. Revista de la Facultad de Medicina de la UNAM, 1, 75-80.

Gómez-Rada, C.A. (2002). Liderazgo, conceptos, teorías y hallazgos relevantes. Cuadernos Hispanoamericanos de Psicología, 2(2), 61-77.

Gordillo, A., Medina, U., \& Pierdant, M. (2012). Manual de investigación clínica. México: Manual Moderno.

Havinal, V. (2009). Management and entrepreneurship. New Delhi: New Age International Publishers.

Hernández, R., Fernández, C., \& Baptista, P. (2006). Metodología de la investigación. México; McGraw Hill.

Lamond, D. (2003). Henry Mintzberg vs Henri Fayol: of lighthouses, cubists and the emperor's new clothes. Journal of Applied Management and Entrepreneurship, 8(4), 5-23.

Lederer, A.L., \& Mendelow, A.L. (1987). Information Resource Planning: Overcoming Difficulties in Identifying Top Management's Objectives. MIS Quarterly, 11(3), 389.

Lopez, M., Hernandez, E., Mejía, G., Cerano, J. (2019). Factors that enable the adoption of educational technology in medical schools. Educacion Medica, 20(3), 9. DOI:10.1016/j.edumed.2017.07.006

Lopez, M., Olivares, S., \& Heredia, Y. (2020). Professional culture in medical schools: a medical educator interpretation. Medical Science Educator, 30, 281-286.

McMillan, J.J., \& Schumacher, S. (2006). Research in Education. Boston: Pearson Education.

Naidu, S.P. (1996). Public Administration: Concepts and Theories. New Delhi: New Age International Publishers.

Olivares, S.L., Garza, A., Lopez, M., \& Suárez, A. (2016). Evaluation of organizational and directional leadership in schools of medicine in Mexico. Innovación Educativa, 16(70), 131-149.

Olivares, S.L., Garza, A., \& Valdez, J.E. (2016). Etapas del modelo incremental de calidad: un análisis de las escuelas de medicina en México. Investigación en Educación Médica, 5(17), 24-31.

Rabin, J., Humes, S., \& Morgan, B.S. (1984). Managing Administration. New York: Marcel Dekker.

Reyes, A. (2007). Administración Moderna. México: Limusa.

Rivas, L.A. (2002). Nuevas formas de Organización. Estudios Gerenciales, 82(1), 13-45.

Vogt, P. (2007). Quantitative research methods for professionals. Boston, MA: Pearson/Allyn and Bacon. 